\title{
Sistem Pendukung Keputusan Dengan Metode Fuzzy Logic Untuk Menseleksi Mahasiswa Penerima Beasiswa
}

\author{
Arman 1), Defiariany 2) \\ ${ }^{1}$ Dosen STMIK Indonesia Padang, Padang 25136 \\ Email: $\underline{\operatorname{arman} 16309 @ g m a i l . c o m}$
}

\begin{abstract}
ABSTRAK
The decision in granting scholarships to students can use the Decision Support System (Decision Support System) by using certain methods, one using fuzzy logic and applied with the Microsoft Visual Basic programming language. Assessment with students who are entitled to receive can be done using several criteria, including the criteria of poverty or disability, criteria dependent parent, criteria value GPA of the semester, the criteria semester, students are being filed, and the criteria of activeness in the organization, especially student organizations on campus. Such criteria conducted with questionnaires, correspondence and interviews. Questionnaires given to each student who apply for a scholarship. Correspondence intended as Student Card, KHS, KK (family card), and other supporting certificate. Interviews were conducted with the questions asked by the parties to the Student Assessment. The assessment results entered into the fuzzy logic using the model Tahani. By determining the input and output variables are used. With the help of fuzzy logic, the decision in selecting scholarship recipients quickly, efficiently and effectively.
\end{abstract}

Keywords: DSS, Fuzzy logic, Tahani, Visual Basic

\section{PENDAHULUAN}

Pada saat sekarang ini computer sudah banyak digunakan oleh instanis baik itu insatansi pemerintahan atau pun swasata untuk memnbtu dalam proses pekerjaan agar lebih efieisin dan efntif, salah satunya di STMIK Indonesia Padang setiap tahun melaksanakan proses penyeleksian mahasiswa calon penerima beasiswa, hal ini perlu dicarikan solusi yang tepat dan cepat dalam menentukan keputusan mahasiswa calon penerima beasiswa STMIK Indonesia Padang yang diperuntuk bagi mahasiswa miskin dan berprestasi hal ini sejalan dengan Peraturan Pemerintah Nomor 66 Tahun 2010 tentang perubahan atas
Peraturan Pemerintah Nomor 17 Tahun 2010 tentang Pengelolaan dan Penyelenggarakan Pendidikan; Peraturan Menteri Nomor 30 Tahun 2010 tentang pemberian bantuan biaya pendidikan kepada peserta didik yang orang tua atau walinya tidak mampu membiayai pendidikan. Beberapa kriteria yang ditetapkan yang harus dipenuhi oleh seorang mahasiswa untuk menjadi calon penerima beasiswa di STMIK Indonesia Padang antara lain: kategori miskin, tanggungan orang tua, nilai indeks prestasi, semester, tingkat keaktifan mahasiswa dalam organisasi. STMIK Indonesia Padang dalam menyeleksi mahasiswa terkendala dalam pemenuhan kriteria-kriteria cenderung dilakukan 


\section{Jurnal Edik Informatika}

ISSN : 2407-0491

E-ISSN : 2541-3716

Penelitian Bidang Komputer Sains dan Pendidikan Informatika

V2.i1(45-52)

secara manual dan kira-kira dengan mengurutkan prioritas dari keteria-kriteria yang ada sehingga memakan waktu yang lama.

Logika Fuzzy dikembangkan dengan meniru cara berpikir manusia yang seringkali bekerja dengan prinsip "kira-kira", hal ini berbeda dengan logika Boolean yang hanya mengenal dua keadaan ya/tidak, benar/salah, logika fuzzy memungkinkan adanya modifikasi terhadap keadaan tersebut dengan tingkat/derajat tertentu sehingga mengijinkan kondisi seperti benar, agak benar, kurang benar, agak salah, dan salah. Meskipun relatif baru, tetapi logika fuzzy telah diaplikasikan di banyak bidang, antara lain pada tahun 1990 pertama kali dibuat mesin cuci dengan logika fuzzy di Jepang. Sistem fuzzy digunakan untuk menentukan putaran yang tepat secara otomatis berdasarkan jenis dan banyaknya kotoran serta jumlah yang akan dicuci. Di bidang manajemen dan pengambilan keputusan, seperti manajemen basis data yang didasarkan logika fuzzy dapat diimplementasikan untuk membantu mahasiswa dalam pengambilan keputusan bidang peminatannya dengan baik dan pengaruh teori logika fuzzy dalam menentukan prestasi mahasiswa Logika Fuzzy dipandang tepat untuk menentukan keputusan mahasiswa calon penerima beasiswa di STMIK Indonesia dengan menirukan cara manusia mengambil keputusan dengan kemampuannya dari data yang samar dan menemukan penyelesaian dalam bentuk keputusan yang tepat dengan menganalisa kriteria-kriteria yang ditetapkan dalam bentuk bilangan pasti (crisp) yang diubah menjadi samar (fuzzy) untuk mendapatkan derajat keanggotaan (fuzzifikasi) dan dihubungkan dengan mesin inferensi (proses penalaran) kemudian dilanjutkan dengan proses merubah hasil penalaran yang berupa derajat keanggotaan keluaran menjadi variable numeric kembali (defuzzifikasi) dan menghasilkan laporan berupa hasil seleksi mahasiswa calon penerima beasiswa yang tingkat rokemendasi tinggi, sedang dan rendah.

\section{LANDASAN TEORI}

\section{Sistem Pendukung Keputusan}

System Pendukung Keputusan merupakan system informasi pada level manajemen dari suatu organisasi yang mengkombinasikan data dan model analisis canggih atau peralatan data analisis untuk mendukung pengambilan keputusan yang semi terstruktur dan tidak terstruktur (Hamzah, Suyono dan Paulus Mudjihahartono,2010).

Konsep Dan Karakteristik Sistem Pengambilan Keputusan adalah proses untuk memilih salah satu alternative tindakan yang digunakan untuk mencapai suatu tujuan tertentu dan merupakan upaya untuk memecahkan persoalan menuju pencapaian suatu tujuan. Pengambilan suatu keputusan pada hakekatnya adalah suatu tujuan proses manajemen (planning, organizing, actuating and controlling) dan pengambilan keputusan dilakukan jika ada kejadian tertentu.

Pada dasarnya pengambilan keputusan adalah suatu pendekatan sistematis pada hakekat suatu masalah, pengumpulan fakta-fakta, penentuan yang matang dari alternatif yang dihadapi dan pengambilan tindakan yang menurut perhitungan merupakan tindakan yang paling tepat (Kadarsyah dan Ali Ramdani, 2004).

Dalam memproses pengambilan keputusan tidak bisa ditentukan sekaligus tetapi dilaksanakan melalui beberapa tahapan. Pada dasarnya, pengambilan keputusan dilakukan melalui empat tahapan, yaitu:

1. Inteligence : mempelajari realitas, identifikasi dan mendefisinikan masalah.

2. Design : membangun model-model yang mewakili sistem, memvalidasi model dan menentukan kriteria evaluasi

3. Choice : membuat solusi untuk modelmodel yang digunakan, menguji solusi, membuat analisis dan memilih alternatif terbaik. 


\section{Jurnal Edik Informatika}

ISSN : 2407-0491

E-ISSN : 2541-3716

Penelitian Bidang Komputer Sains dan Pendidikan Informatika

V2.i1(45-52)

4. Implementasi : menerapkan solusi yang sudah diputuskan untuk melihat sejauh mana solusi tersebut dapat menyelesaikan masalah.

\section{Logika Fuzzy}

Menurut Agus Naba (2009) Sistem fuzzy adalah sebuah sistem yang dibangun dengan definisi, cara kerja dan deskripsi yang jelas berdasarkan pada teori logikafuzzy. Logika fuzzy adalah metodologi "berhitung" dengan variabel kata-kata (linguistic variabel). Logika fuzzy telah menjadi area riset yang mengagumkan karena kemampuannya dalam menjembatani bahasa mesin yang serbapresisi dengan bahasa manusia yang cenderung tidak presisi, yaitu hanya degan menekankan pada makna atau arti (significance).

Dengan logika fuzzy, sistem kepakaran manusia bisa diimplementasikan kedalam bahasa mesin secara mudah dan efisien.

Logika fuzzy adalah suatu cara yang tepat untuk memetakan suatu ruang input kedalam suatu ruang output. Pemetaan atau mapping hubungan input dan output dari suatu sistem berdasarkan data input-output. Di antara input dan output kita atur sebuah sistem black box yang akan melakukan tugas pemetaan.

\section{Fuzzy DataBase Model Tahani}

Berdasarkan buku panduan fuzzy database yang disusun oleh Sri Kusumadewi dan Hari Purnomo, telah dijelaskan bahwa database adalah kumpulan dari data yang saling berhubungan satu dengan yang lainnya, tersimpan di perangkat keras komputer dan digunakan perangkat lunak untuk memanipulasinya. Database sistem adalah suatu sistem informasi yang mengintegrasi kumpulan data yang saling berhubungan satu dengan lainnya dan membuatnya tersedia untuk beberapa aplikasi dalam suatu organisasi.

Fuzzy Tahani adalah salah satu cabang dari logika fuzzy, yang merupakan salah satu metode fuzzy yang menggunakan basis data standar. Tahani mendeskripsikan suatu metode pemrosesan query fuzzy, dengan didasarkan atas manipulasi bahasa yang dikenal dengan nama SQL (Structured QueryLanguage), sehingga model fuzzy tahani sangat tepat digunakan dalam proses pencarian data yang tepat dan akurat (Kusumadewi, 2004). Fungsi query diasumsikan sebuah query konvesional basis data yang akan mencoba membuat dan menerapkan sebuah sistem dasar logika fuzzy query. Kelebihan query dari database, pananganan error otomatis, pencarian yang flexsibel. Konsep dari sebuah BDMS merupakan derajat keanggotaan $\mathrm{u}$ yang didefenisikan pada kumpulan domain $\mathrm{x}=\{\mathrm{x} 1$..xn $\}$, yang telah digenerate pada relasi luar oleh nilai tengah fuzzy.

\section{Beasiswa di STMIK Indonesia Padang}

Dalam rangka mendukung program
pemerintah untuk meningkatkan mutu pendidikan dan mewujudkan tenaga yang berkualitas dan professional, tentunya dibutuhkan potensi akademik yang tinggi dan memadai. Maka STMIK Indonesia Padang sebagai salah satu institusi perguruan tinggi harus memiliki usaha yang menunjang demi terwujudnya potensi akademik tersebut. Adapun salah satu usaha yang dilakukan adalah dengan melakukan penjaringan dan penyeleksian terhadap nilai prestasi mahasiswa yang berkualitas dan mahasiswa yang kurang mampu. Setelah itu diberikan dukungan dengan cara membantu biaya pendidikan mereka sehingga tercapai keinginan dan tujuan seperti yang diharapkan.

5. Langkah ini ditempuh adalah dalam rangka meringankan beban mahasiswa yang memiliki prestasi akademik yang tinggi dan atau mahasiswa yang kurang mampu, namun sering terkendala oleh masalah kekurangan biaya dan sebagainya, sehingga sulit untuk menyelesaikan perkuliahan sesuai dengan ketentuan yang berlaku. Maka hal ini diharapkan mampu membantu dan memotivasi mereka dalam 


\section{Jurnal Edik Informatika}

ISSN : 2407-0491

E-ISSN : 2541-3716

Penelitian Bidang Komputer Sains dan Pendidikan Informatika

V2.i1(45-52)

meyelesaikan perkuliahan dan memacu potensi akademis yang lebih tinggi.

\section{METODE PENELITIAN}

Metode penelitian yang digunakan dalam penelitian ini sebagai brikut:

1. Penelitian Labor (Laboratory Research)

Suatu metode riset yang digunakan dalam penelitian, dengan cara pengujian labor dan alat-alat yang digunakan dalam Sistem Pendukung Keputusan dengan metode fuzzy logic untuk menseleksi mahasiswa penerima beasiswa pada STMIK Indonesia Padang, Propinsi Sumatera Barat.

2. Penelitian Perpustakaan (Library Research)

Pembuatan laporan ini dilakukan dengan cara mempelajari dan mengembangkan ilmu pengetahuan yang penulis dapatkan dari para pengajar dan media online yang dinilai akurat dalam pembuatan sistem ini.

3. Penelitian Lapangan (Field Research)

Suatu metode riset mengamati langsung ke Instasi STMIK Indonesia Padang pada pada pimpinan, dalam hal ini dilakukan survei untuk mempelajari atau menganalisa sistem yang sedang berjalan serta kemungkinankemungkinan lain yang dapat membantu dalam mengembangkan sistem yang telah ada menjadi sistem yang lebih bermanfaat dan lebih optimal.

4. System Development Life Cycle (SDLC)

Merupakan alat bantu penting dalam metodologi pengembangan perangkat lunak. Tujuannya adalah agar pengembangan sistem informasi menjadi lebih cermat, terstruktur dan mengikuti metode yang telah ditentukan oleh pimpinan STMIK Indonesia Padang.

\section{HASIL DAN PEMBAHASAN}

Deskripsi Sistem

Sistem pendukung keputusan seleksi penerima beasiswa menggunakan logika fuzzylogic tahini ini digunakan untuk mendapatkan rekomendasi ke pimpinan mahasiswa mana yang akan mendapatkan beasiswa yang telah memenuhi kriteria-kiteria dari input yang sudah ditentukan.

Kebuutuhan input sistem untuk variable kriteria-kriteria dalam menseleksi mahasiswa penerima beasiswa, yang terdiri dari 8 variabel yaitu : nilai ketidak mampuan/miskin, nilai etika, nilai keantifan dalam organisasi, nilai kehadiran/absensi, nilai IPK, nilai Semester, nilai tanggung jawab orang tua dan nilai umur mahasiswa.

Setiap variable fuzzy menggunakan representasi kurva bahu dan kurva segitiga pada garafik fungsi keanggotaannya.

1.Kriteria ketidak mampuan/miskin, Nilai lingustik pada variable ketidak mampuan ada 4 , yaitu :

- Tidak miskin (misalnya 0-60)

- Hampir miskin (misalnya 40-80)

- Miskin (misalnya 60-90)

- Sangat miskin (misalnya 80-100)

Dengan grafik fungsi keanggotaan akan tampil seperti gambar 1.

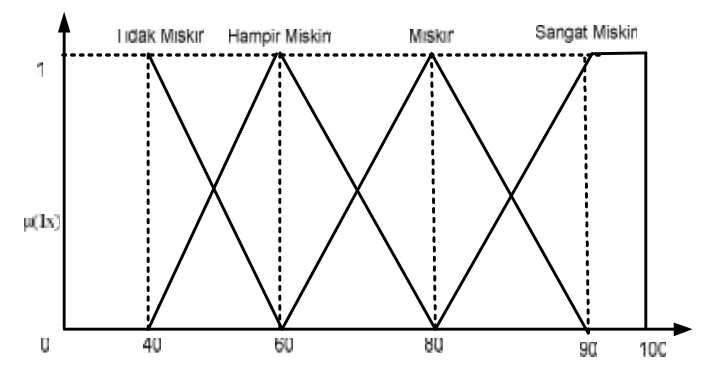

Gambar 1 Fungsi Keanggotaan Kriteria Ketidak mampuan

Maka funsi keanggotaan untuk nilai variable ketidak mampuan dapat dirumuskan sebagai berikut :

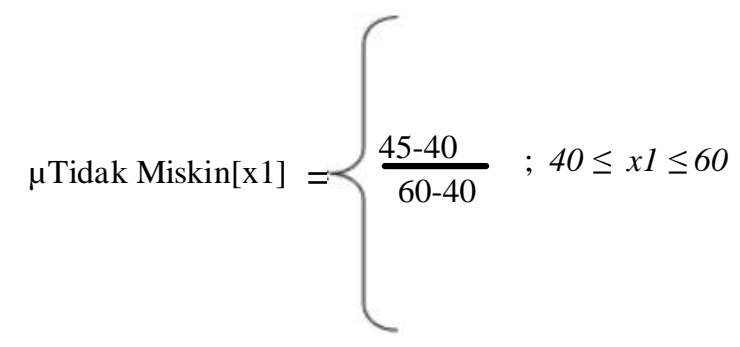




\section{Jurnal Edik Informatika}

ISSN : 2407-0491

E-ISSN : 2541-3716

Penelitian Bidang Komputer Sains dan Pendidikan Informatika V2.i1(45-52)

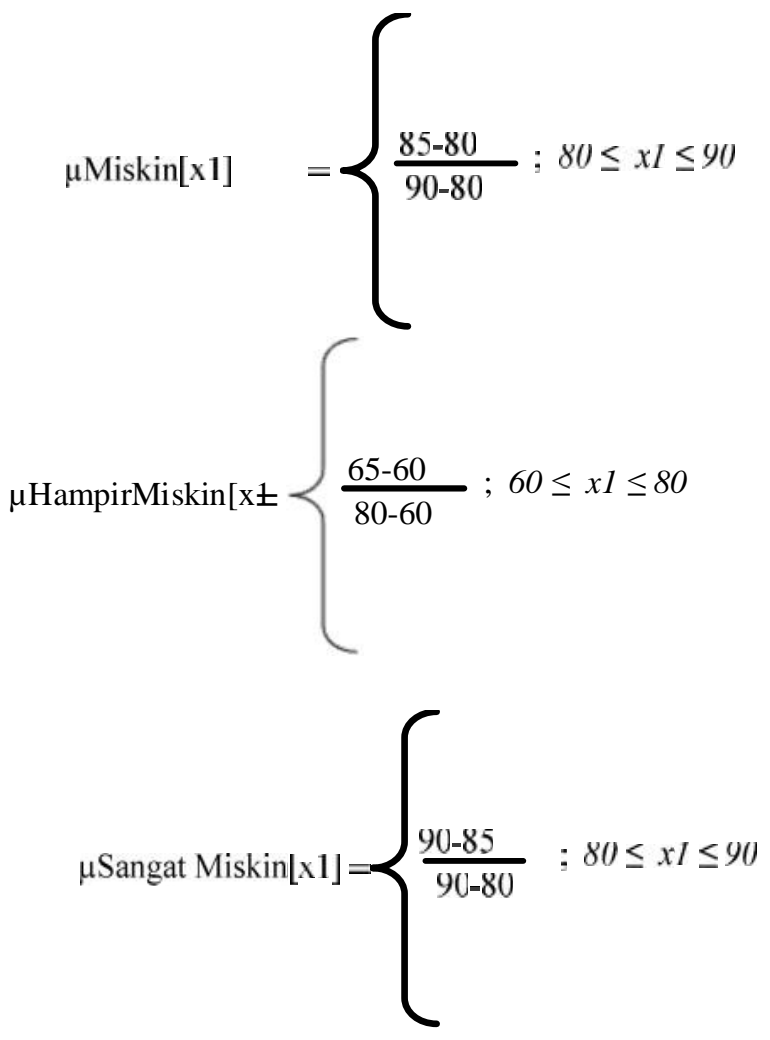

2.Kriteria etika, Nilai lingustik pada variable etika ada 3, yaitu :

- Kurang (misalnya 0-70)

- Cukup (misalnya 60-80)

- Baik (misalnya 70-100)

Dengan grafik fungsi keanggotaan akan tampil seperti gambar 2 .

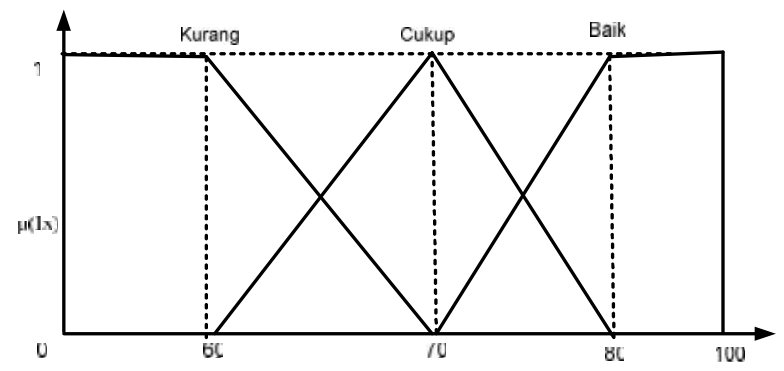

\section{Gambar 2 Fungsi Keanggotaan Kriteria Etika}

Maka funsi keanggotaan untuk nilai variable ketidak mampuan dapat dirumuskan sebagai berikut :
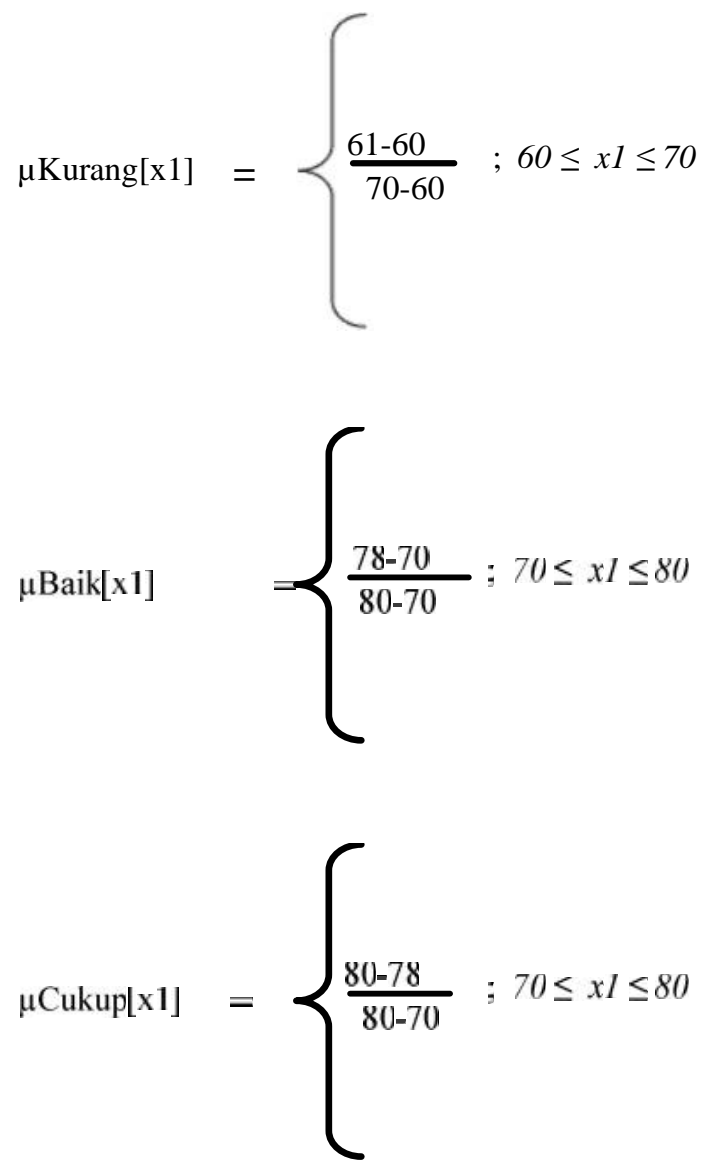

untuk Ouputnya sistem yang dapat menberikan alternative solusi untuk pengambilan kepuutusan yang dikakukan oleh pimpinan, yang dapat membantu dalam memberikan rekomendasi kepada pimpinan untuk pengambilan keputusan, sehingga akan lebih mudah digunakan untuk parameter penilaiaan karena lebih mudah digunakan dan mudah dipahami. Dengan menggunakan logika fuzzy model tahini sebagai metode pada sistem ini. Maka sistem ini akan diharapkan akan dapat menyelesaikan permasalahan yang dihadapi dalam pemilihan mahasiswa yang akan mendapatkan beasiswa, maka hasil keluaran yang didapatkan memiliki nilai kelenturan terhadap grafik fungsi keanggotaan dari himpunan fuzzy setiap variable. Sebagai sistem pendukung keputusan tentu hasil sistem berupa alternative, namun peran SPK sebagai penunjang keputusan diharapkan dapat 


\section{Jurnal Edik Informatika}

ISSN : 2407-0491

E-ISSN : 2541-3716

Penelitian Bidang Komputer Sains dan Pendidikan Informatika

V2.i1(45-52)

dijadikan pertimbagan dalam mengambil sebuah keputusan..

\section{Implementasi Sistem}

Pada menu utama program SPK seleksi mahasiswa penerima beasiswa, terdapat tombol akses untuk masuk kedalam sistem, program aplikasi terdiri dari beberapa menu yaitu menu input, proses dan ouput. Untuk lebih jelasnya dapat dilihat pada pembahasan berikut:

\section{Input}

Form entri data yang digunakan untuk memasukan data-data mahasiswa yang ikut seleksi untuk lebih jelasnya dapat dilihat pada gambar berikut ini:

\section{a. Menu Utama}

Menu utama pada Sistem Pendukung Keputusan dengan metode Fuzzy logic Untuk seleksi Mahasiswa Penerima Beasiswa Di STMIK Indonesia padang Memiliki menu entri, menu proses, menu laporan dan menu keluar. Fungsi menu entri yaitu menginputkan data-data mentah ke dalam database. Form yang terdapat dalam menu entri adalah form calon Mahasiswa, form nilai nilai mahasiswa. Pada menu proses terdapat form Rekomendasi data mahasiswa yang akan diproses data calaon penerima beasiswa. Pada form laporan terdapat form pembuatan laporan calaon mahasiswa yang dinyatakan lulus, tidak lulus dan yang dipertimbangkan, serta menu keluar untuk mengakhiri jalannya program. Untuk lebih jelasnya dapat dilihat pada gambar berikut:

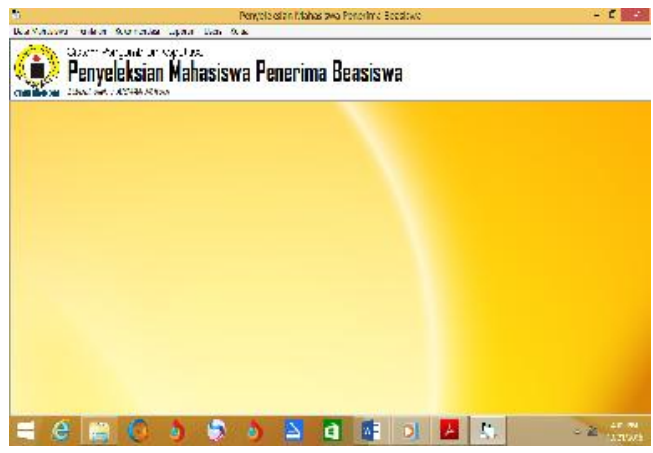

Gambar 1. Menu Utama Sistem Pendukung Keputusan Untuk Seleksi Mahasiswa Penerima Beasiswa Dengan Metode Fuzzy Logic

\section{b. Input Data Mahasiswa}

Form input data mahasiswa bergungsi untuk meenry data mahasiswa yang akan ikut seleksi untuk mendapatkan beasiswa. Aapun data-data yang diinputkan dapat dilihat pada Gambar berikut:

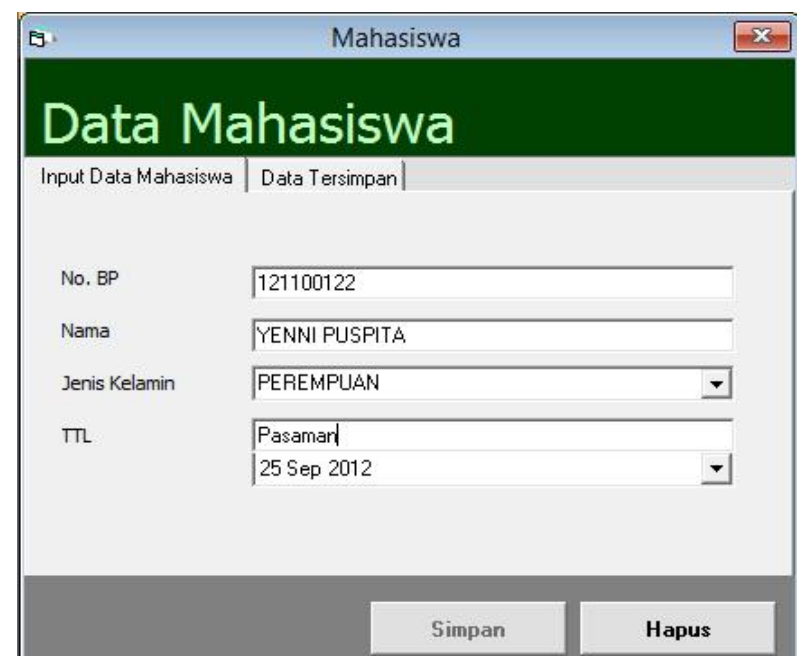

Gambar 2. Form Input Data Mahasiswa

c. Input Data Nilai Mahasiswa

Form input data Nilai Mahasiswa yang ikut seleksi penerima beasiswa dan dienrykan nilai variable masasiswa tersebut yang terdiri dari 8 variabel seperi nilai keridakmampuan, Erika,aktif dalam organisasi, ansensi, IPK, Semester, 


\section{Jurnal Edik Informatika}

Penelitian Bidang Komputer Sains dan Pendidikan Informatika

tangung jawab orang tua dan nila variable umur mahasiswa. Bentuk datadata yang diinputkan dapat dilihat pada Gambar berikut:

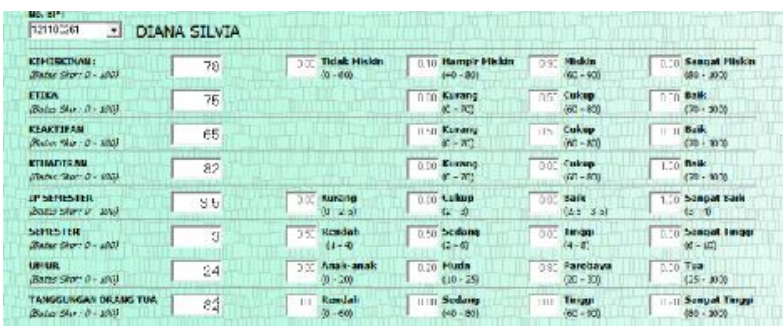

Gambar 3.Form Input Data Nilai Mahasiswa

\section{Proses}

Pada fuzzy untuk prosesnya untuk menu pengaturan atau konfigurasi batas nilai berfungsi untuk membentuk grafik fungsi keanggotaan setiap variable fuzzy pada sistem dengan menggunakan batas nilai lingustiknya. Proses fuzyfikasi terjadi pada saat data nilai kriteria diimputkan kemudia data mahasiswa disimpan otomasis melakukan proses yang dijalankan.

\section{Output}

a. Laporan nilai mahasiswa

laporan output merupakan jembatan untuk menghasilkan laporan rekomendasi mahasiswa yang lulus seleksi atau tidak. Untuk laporan dapat dilihat pada Gambar 4 berikut:

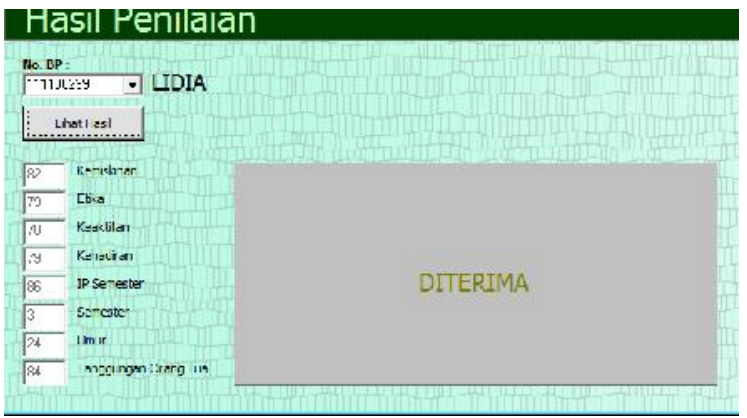

\section{Gambar 4. Laporan rekomendasi mahasiswa yang lulus seleksi}

yang sesuai dengan nilai kriteri yang sudah ditentukan oleh pimpinan dan diurutkan berdasarkan nilai stength untuk mengtahuai mahasiswa nama yang paling mendekati kesesuain terhadap kriteria pimpinan dapat dilihat pada gambar 5 sebagai berikut :

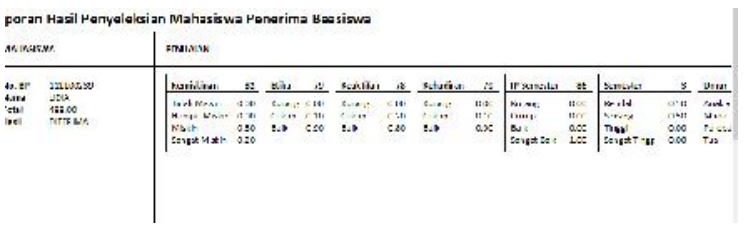

\section{Gambar 5 laporan nilai kriteria-kriteria mahasiswa}

\section{KESIMPULAN}

Berdasarkan hasil penelitian dan implementasi sistem, maka dapat diambil kesimpulan bahwa :

1. Sistem pendukung Keputusan dengan metode Fuzzy Logic Tahani dapat membantu pimpinan untuk mendapatkan rekomendasi dalam seleksi mahasiswa dalam penerima beasiswa.

2. Motode Fuzzy Database model tahini merupakan salah satu metode yang tepat untuk digunakan pada sistem perekomendasian dan pendukung keputusan bagi pimpianan dalam penyelesaikan permasalahan yang relative.

3. Hasil akhir dari penelitian ini bahwa aplikasi yang dibangun dapat membantu menghasilkan keputusan yang lebih cepat untuk dijadikan bahan pertimbangan dalam penyeleksian mahasiswa penerima beasiswa.

4. Sistem ini tidak akan dapat memberikan hasil yang benar apabila kriteria yang dimasukkan tidak lengkap, sehingga penilai dapat menentukan sendiri kriteria yang diinginkan.

Saat sfat melakukan input data nilai mahasiswa menekan tombol simpan pada form rekomendasi, sistem akan melakukan proses query pada database dan menampilkan data mahasiswa 


\section{Jurnal Edik Informatika}

E-ISSN : 2541-3716

Penelitian Bidang Komputer Sains dan Pendidikan Informatika V2.i1(45-52)

\section{DAFTAR REFERENSI}

Agus Naba, 2009, "Belajar cepat Fuzzy Logic Menggunakan MATLEB," Penerbit CV. ANDI OFFSET

Dadan Umar Daihani. (2005) "Komputasi Pengambilan Keputusan", penerbit oleh PT. Elex Media Komputindo Kelompok Gramedia Jakarta.
----------------------, 2001, “ “ Komputerisasi Penganbilan Keputusan, “Penerbit PT. Elex Media Komputindo

Jogiyanto, 2009, "Sistem Teknologi Informasi," Penerbit ANDI Yogyakarta

Kusrini, 2007 ,’Konsep DanAplikasi Sistem pendukung putusan," Penerbit ANDI Yogyakarta

Sri Kusumadewi \& Hari Purnomo, 2010, ”Aplikasi Logika Fuzzy Untuk Pendukung Keputusan", Penerbit GRAHA ILMU 